\title{
LA TACHADURA DE UN "YO": MEMORIAS DE LA ROSA (2000), CONSUELO DE SAINT-EXUPÉRY
}

\author{
CARla Rodríguez Corrales \\ Universidad de Costa Rica; Universitat Autònoma de Barcelona
}

\begin{abstract}
En 1946 la escritora y artista salvadoreña Consuelo Suncín Sandoval (1901-1979) escribe Memorias de la rosa, texto autobiográfico-memorial publicado póstumamente en el 2000, año del centenario del nacimiento de su marido, el aviador y escritor francés Antoine de Saint-Exupéry (1900-1944). Parte de la crítica, de la cual forma parte el prefacio de la primera edición en castellano de esta obra, entroniza la imagen mítica del renombrado autor, operación que obtura la propuesta textual y eclipsa a la autora salvadoreña. Este menoscabo evidencia la correlación existente entre el posicionamiento de las obras y las marcas corporales de los sujetos que ocupan la función autorial, hecho que se convierte en invitación a revisitar el texto desde la configuración corpo-autorial del "yo" para contribuir a saldar una deuda historiográfica con la figura y la obra de esta escritora centroamericana. En estas coordenadas gravita esta aproximación.
\end{abstract}

PALABRAS CLAVE: autoría femenina, memorias centroamericanas, género y escritura.

\section{The Erasure of an "I": Memorias de la rosa (2000), Consuelo de Saint-Exupéry}

In 1946, Salvadoran woman writer and artist Consuelo Suncín Sandoval (1901-1979) writes Memorias de la rosa, an autobiographic-memorial text posthumously published in 2000, on the centenary of the birth of his husband, French aviator and writer Antoine de Saint-Exupéry (19001944). A part of the critique, where the preface of the first Spanish edition of this work stands out, enthrones the mythical image of the renowned author, an operation that obscures the textual proposal and overshadows the Salvadoran woman author. Such impairment highlights the correlation between the positioning of the works and the bodily stigma of the subjects who occupy the authorial purpose, which turns it into an invitation to revisit the text from the bodilyauthorial configuration of the "I" to contribute to settle a historiographic debt towards the figure and work of this Central American woman writer. These are the coordinates in which this approach gravitates.

KEY WORDS: female authorship, Central American memoirs, gender and writing.

Rodríguez Corrales, Carla (2021), "La tachadura de un 'yo': Memorias de la rosa (2000), Consuelo de Saint-Exupéry", Lectora, 27: 89-106. ISSN: 1136-5781 D.O.I.: 10.1344/Lectora2021.27.4, carla.rodriguezcorrales@ucr.ac.cr

Recepció: 8 de desembre de 2020 - Acceptació: 18 de maig de 2021 
Las memorias ${ }^{1} \mathrm{y}$, de forma extensiva, las narrativas autobiográficas ${ }^{2}$ nacen del vértigo de lo humano, del intento de perpetuación de los sujetos al saberse tiempo. Tanto su ejercicio, lectura como teorización conducen a formular incómodas preguntas acerca de su estatus, límites y pretensiones: ¿es posible volcar el "yo" sobre la página en blanco?, ¿trasladar el pasado y la experiencia al lenguaje?, ¿existen puentes que unen el recuerdo y la escritura?, ¿acaso el "yo" es justamente el resultado de ese tejido discursivo? Procurar responder a ello de modo definitivo sería reduccionista, pues cada relato del "yo" (en su escritura y lectura) teje una posible respuesta. Partiendo de ello, el siguiente estudio se aproxima a Memorias de la rosa (2000), obra de la autora salvadoreña Consuelo Suncín Sandoval (1901-1979), con el fin de indagar de qué modo se lleva a cabo la configuración retórica de la imagen-voz del "yo" memorial-autorial. Por lo tanto, nos parece necesario trazar las coordenadas teóricas que guían el análisis y que conducen a definir el espacio autobiográfico-memorial. En tal sentido, se recurre al término espacialidad con el fin de ensanchar los límites que tradicionalmente se imponen a los procesos de escritura-lectura de diarios, epístolas, crónicas, autobiografías, memorias, testimonios, relatos de viaje. El visualizar estas prácticas como territorio extensivo posibilita repensarlas como sitios de convocatoria, creación y resignificación, donde las voces memoriales se figuran retóricamente como prosopopeyas para reclamar su existencia y lugar simbólicos.

Resulta clave advertir que la práctica literaria, en tanto proceso de producciónrecepción, es ante todo un hecho histórico, dialógico y multidimensional. Esto significa que opera en función de determinadas estructuras ideológico-discursivas y búsquedas estético-políticas, las cuales a su vez se circunscriben a las exigencias específicas de sus contextos. Reconocer esta naturaleza conduce a asumir el espacio autobiográfico-memorial como código lecto-escritural, cuyo despliegue condiciona la dinámica de escritura y lectura de las narrativas del “yo". Así, la voz autobiógrafa-memorialista no actúa como transcriptora de una realidad pasada, no solo a razón de que la experiencia y el tiempo resultan inaprehensibles y el lenguaje insuficiente, sino también porque el relato del "yo" supone ante todo leerse, esto es: interpretarse, crearse desde la profusión de espacios y tiempos

\footnotetext{
${ }^{1}$ Las memorias conforman una escritura situada en el pasado, donde una voz en primera persona narra un acontecimiento o hecho significativo de su historia personal mediante la articulación o recuperación de su historicidad. Se trata de una escritura que registra la lectura-interpretaciónrecuerdo de sucesos concretos y las transformaciones colectivas e individuales derivadas de éstos. Su impulso responde, en gran medida, al propósito de hacer memoria, dejar constancia de lo sucedido y evitar el olvido, motivaciones que poseen un cariz claramente político.

${ }^{2}$ Este estudio emplea las denominaciones narrativas autobiográficas y espacio autobiográficomemorial para referir aquellas escrituras que apuestan por narrar, desde la posición enunciativa de la primera persona del singular, la vida-voz-rostro de un "yo" texto-imaginario.
}

90

Lectora, 27 (2021): 89-106. ISSN: 1136-5781 D.O.I.: 10.1344/Lectora2021.27.4 
fragmentados, difusos; huellas históricas y marcas culturales; estructuras ideológicas, normas, patrones de género, clase, etnia y recuerdos inventariados por la memoria. Así, en un segundo momento, la lectora/lector, escribe, dota de rostro y sentido al "yo" textual, desde su propio código, mirada y experiencia. En esta línea, Jacques Derrida concibe el espacio autobiográfico-memorial como una figura de lectura que adquiere forma-lugar en la relación especular: "La firma no ocurre en el momento de la escritura, sino cuando el otro me escucha. El destinatario de la autobiografía escribe en lugar del autobiografiado. La oreja del otro firma por mí, me dice, constituye mi yo autobiográfico. El yo pasa siempre por el otro" (Loureiro, 1991: 7). En síntesis, si "[...] la alegoría de la lectura es la escritura [...]" (Derrida, 1998: 108), el paso de la escritura a través del otro, "convierte lo autobiográfico en heterobiográfico" (Loureiro, 1991: 7).

En concordancia con lo expuesto, la presente aproximación rehúye de las posiciones más tradicionales que envían a orbitar en la periferia del sistema literario a las narrativas autobiográficas-memoriales por considerarlas textualidades desprovistas de literariedad (fuerza inventiva, imaginación) y portadoras de un valor mimético-referencial que las hace merecedoras de la credencial géneros menores, distinción que sella su marginalidad frente a la ficción. Por ello, como contrapunto, siguiendo a Paul De Man, este estudio asume lo autobiográfico como hecho lingüístico o ejercicio retórico basado en la prosopopeya, figura retórica que persigue otorgar vida a lo que no lo posee, presencia y máscara a lo ausente, pasado: "En la medida en que el lenguaje es figura (metáfora o prosopopeya), es realmente no la cosa misma, sino su representación, la imagen de la cosa" (De Man, 1991: 116). Aceptar esto implica, a su vez, admitir que el proceso lecto-escritural de lo autobiográfico-memorial produce y determina el "yo"-textual y no a la inversa: "el yo no es así un punto de partida, sino lo que resulta del relato de la propia vida" (Catelli, 1991: 17), la prosopopeya que toma cuerpo en el proceso de narrar, de crear. Así, al margen de toda convención, el "yo"3 es, ante todo, materialidad lingüística, no materialidad extratextual tangible, referencial.

Las premisas antes esbozadas conforman el portal de entrada desde el que se analiza el texto de Suncín: por un lado, presta atención a las lecto-escrituras

\footnotetext{
${ }^{3}$ Ricœur insiste en remarcar su naturaleza lingüística al reconocerlo como signo: “ ¿No desaparece el 'yo', en cuanto yo, desde el momento en que se confieren al enunciado dos referencias de dirección opuestas, la una hacia la cosa significada y la otra hacia la cosa significante? De hecho, el deslizamiento estaba contenido en la definición del signo heredada de los antiguos: una cosa que representa a otra cosa" (Ricœur, 1996: 27-28). Por tanto, no existe una equivalencia referencial, alguien externo a la narración que corresponda al "yo". El "yo" se crea a sí mismo cada vez que se designa al narrar. "Tiene un nuevo significado cada vez que se usa y cada vez que se refiere a un sujeto singular. 'Yo' es aquel que al hablar se adjudica así mismo la palabra 'yo'” (Ricœur, 2003: 27). Narrarse es sinónimo de crearse, hacerse texto, lenguaje.
} 
fosilizadas, aquellas generadas por "la oreja del otro", como apunta Derrida, y que en este caso corresponde a Alain Vircondelet, autor del prólogo de la primera edición de la obra en castellano. Y, por otro, resigue los hilos narrativos que procuran dar vida/personificar, en sentido retórico-figurativo, el "yo" texto-autorial. Los siguientes apartados se articulan alrededor de dicho propósito.

\section{Consuelo de Saint-Exupéry: sujeto de tachadura}

Consuelo Suncín Sandoval, conocida comúnmente como Consuelo de Saint-Exupéry (1901-1979), nace en Armenia, Sonsonate, El Salvador, en el seno de una familia de ricos terratenientes. Realiza sus estudios en el Instituto Central de Señoritas y recibe una beca para estudiar inglés en la ciudad de San Francisco, Estados Unidos. En México, inicia la carrera de Derecho, la cual abandona para estudiar periodismo, época en la cual establece contacto con figuras del círculo literario y cultural. Más tarde, se traslada a Francia, donde se casa con el escritor guatemalteco Enrique Gómez Carrillo, de quien enviuda en 1927, once meses después de contraer nupcias con él.

En 1946 Consuelo de Saint-Exupéry escribe Memorias de la rosa, dos años después del trágico fallecimiento de su marido, el escritor y piloto francés Antoine de Saint-Exupéry. ${ }^{4}$ El texto permanece inédito durante cincuenta y un años hasta 1997, cuando José Martínez Fructuoso, antiguo jardinero, mayordomo y heredero universal de Consuelo, decide dar a conocer el manuscrito que había encontrado en un antiguo baúl junto a otros documentos, fotografías y cartas. La publicación se efectúa en el 2000, año del centenario del nacimiento de Antoine de Saint-Exupéry. Las memorias originalmente escritas en francés llegan a popularizarse sobre todo en Francia, sin embargo, su lectura y recepción invisibiliza a la autora y coloca toda la atención en el mítico escritor.

La primera edición al castellano de Memorias de la rosa es una traducción de Francisco Rodríguez de Lecea y Albertina Rodríguez Martorell para Ediciones B y cuenta con un prefacio de Alain Vircondelet, cuya propuesta de lectura - valga subrayar - se convierte en el punto de partida de esta aproximación. Los paratextos de una obra literaria, como sostiene el clásico estudio de Gérard Genette (1989), son una vía para tejer relaciones y redes transtextuales. Por tanto, no son

\footnotetext{
${ }^{4}$ Antoine Marie Jean-Baptiste Roger Conde de Saint-Exupéry (1900-1944) pertenece a una familia aristócrata de Lyon, Francia. Tras cumplir su servicio militar en las fuerzas aéreas francesas, decide convertirse en piloto, su pasión más grande, seguida de la escritura. En 1929 es enviado a Buenos Aires para dirigir la Aeroposta en Argentina, donde conoce a quien sería su esposa: Consuelo Suncín Sandoval. Entre sus obras se encuentran: El aviador (1926), Correo del Sur (1928), Vuelo nocturno (1930), Tierra de hombres (1939), Piloto de guerra (1942), El principito (1943). Muere a causa de un accidente de aviación.
}

92 
meramente un asunto protocolario, de trámite o estructura formal. Lo paratextual es homologable a la firma de institucionalidad literaria, la pertenencia o la desvinculación a determinado círculo, grupo, élite, similar al sello editorial. Su escritura posee un carácter performativo, en la medida en que dicta sentencia a la obra y a su autora-autor. A razón de ello, la palabra paratextual no es inocua, traza destinos literarios.

Del prólogo de Alain Vircondelet cabe destacar tres ejes para esta discusión: la referencia al perfil y la posición de la autora construido por la crítica, la propuesta de lectura (cómo debería ser leído el texto) y la función que se supone desempeñan las memorias. El prologuista brinda un somero retrato de Consuelo de Saint-Exupéry a partir de las voces de sus tres biógrafos -Paul Webster (1993), Marie-Hélène Carbonel y Martine Fransioli Martínez (2010) - , quienes la reconocen y definen como la esposa de un célebre hombre de letras. Sumada a esta eclipsación, la autora salvadoreña es concebida fuera de lugar, un elemento discordante dentro del mundo aristocrático de Saint-Exupéry, debido mayormente al presunto conservadurismo cultural y religioso que la caracteriza y la vuelve "incompatible" con el mundo artístico y bohemio de su marido: "Difícilment SaintExupéry hauria pogut escollir una dona que pogués oposar-se millor amb els conceptes socials i tradicionals de la seva família, malgrat que ell mateix havia manifestat la voluntat de trencar amb un estil de vida conservador" (Webster en Gay, 2001: 40). Dicha asignación parece obedecer en gran medida al origen étnico de la autora y la herencia de prejuicios colonialistas asociados a la inferioridad cultural, el tardío progreso económico y la inestabilidad política de la región centroamericana. Siendo así, la imagen de Consuelo Suncín como mujer conservadora que se opone a la liberalización de su marido debe leerse como una marca que imprime la diferencia frente al otro europeo ${ }^{5}$ debido a la procedencia marginal y periférica. Posición que se evidencia en el siguiente fragmento: "Els biògrafs de Saint-Exupéry no han estat benèvols amb la seva esposa: 'Els que coneixien els seus gustos [els de l'escriptor] no es podien creure que desitgés seriosament casar-se amb una persona petita i morena i que no sols no era francesa, era sud-americana!', escriu Curtis ${ }^{6}$ Cate" (Cate en Gay, 2001: 39-40). En este sentido, la marginalidad de Suncín obedece tanto a valores xenófobos como de clase. Por ello, ante la mirada social, poco o nada pesa que se trate de una mujer con educación y que en su país pertenezca a

\footnotetext{
${ }^{5}$ En el estadio intercultural el otro constituye la alteridad construida en un marco estructural sociohistórico y narrativo, cuya representación imaginaria responde al temor y la amenaza que la diferencia prefijada supone para el "yo" (sea éste singular o colectivo): los pueblos nativos ante la mirada de sus colonizadores; los inmigrantes frente a las naciones de acogida; Oriente en relación con Occidente.

${ }^{6}$ Cate es autor de la biografia titulada Saint-Exupéry, publicada en 1973.
} 
una clase social acomodada; desde la óptica europea o, más específicamente francesa, ella no alcanza a estar a la altura del conde De Saint-Exupéry. Su estatus no es homologable, solo puede estar a su sombra.

A dicha construcción se adhieren dos rasgos más que la desmarcan: la hostili$\operatorname{dad}^{7}$ que - se afirma - muestra Consuelo frente al modo de vida bohemio de su esposo y amigos artistas, lo cual respalda la idea de no pertenencia al círculo, su autoexclusión; y en segundo lugar, la reputación de "mujer seductora", oportunista y casamentera, inscripciones basadas en sus relaciones con figuras públicas como el escritor y diplomático guatemalteco Enrique Gómez Carrillo (1873-1927) y el político y escritor mexicano José Vasconcelos (1882-1959). Dicho perfil sustentado en la frivolidad de los rumores y los roles sexo-genéricos que censuran la libertad sexual de las mujeres soslayan y ponen en entredicho la trayectoria artística de Suncín como pintora, escultora y escritora. De tal manera, la subjetividad de Suncín queda reducida a la imagen de una mujer-objeto, infiel y coqueta, a partir de un aparato biográfico, que en realidad se sustenta en saberes reducidos sobre la vida de la autora. Paralelo a las imágenes creadas por los biógrafos, la figura de Consuelo Suncín es desacreditada por los parientes del escritor (con excepción de Marie de Saint-Exupéry, su suegra) y por los amigos de Antoine: "la condesa de opereta", "personilla extravagante y caprichosa", "charlatana que habla mal el francés” (Vircondelet en De Saint-Exupéry, 2000: 13). De allí que, sin reparo alguno, Vircondelet afirme que Suncín engendra "desorden en el mito"8 construido alrededor del escritor francés.

En congruencia con estas figuraciones articuladas desde retóricas patriarcales y xenófobas, Vircondelet desplaza la propuesta de lectura de Memorias de la rosa

\footnotetext{
${ }^{7}$ Aun cuando Consuelo Suncín cuenta con una formación académica, algo inusual para una mujer en 1930, ello resulta insuficiente: "[...] es la extranjera de la familia y desentona en las veladas literarias de la Nouvelle Revue Française [...] porque en los salones a los que asiste Saint-Exupéry se prefiere a mujeres mucho más emancipadas, intelectuales, libertinas o de negocios. Consuelo, como le reprocha Tonio, 'hace ostentación de sus devociones religiosas', invoca a Dios y a todos los santos, va a la iglesia, se confiesa regularmente y reza por su marido cuando éste parte a una misión [...]" (Vircondelet en De Saint-Exupéry, 2000: 19).

${ }^{8}$ Configuración que dista y contrasta con la expuesta por Teresa Fallas (2013) en Escrituras del yo femenino en Centroamérica 1940-2002. De acuerdo con este estudio, la autora salvadoreña y sus obras Memorias de Oppède (1945) y Memorias de la rosa (1946) son precursoras de la escritura autobiográfica centroamericana, junto a los trabajos de la hondureña-guatemalteca Argentina Díaz Lozano, Peregrinaje (1943); la hondureña Lucila Gamero Moncada, Autobiografía de Lucila Gamero de Medina (1952) y la salvadoreña Claudia Lars con su memoria poética Tierra de infancia (1959). Para Fallas, estas obras y autoras son claves porque "[...] inician el rescate y valoración de la autoría femenina en Centroamérica. En su empeño por replantear la subjetividad femenina, estas mujeres reivindican su propia autoría" (2013: 47).
}

94

Lectora, 27 (2021): 89-106. ISSN: 1136-5781 D.O.I.: 10.1344/Lectora2021.27.4 
(2000) a la figura de Antoine de Saint-Exupéry. Es decir, traza la tachadura de Consuelo al sublimar el "yo" narrativo y la autoría. Para tal efecto, apunta que el texto memorial constituye un compendio de recuerdos de la pareja, escrito desde lo afectivo "para escapar a la amargura y la desesperación" (Vircondelet en De Saint-Exupéry, 2000: 15), emociones surgidas a raíz de la pérdida y el duelo de la viuda y autora. Esta operación feminiza el contenido de la obra al otorgarle un valor sentimental (lacrimoso) y subjetivo en detrimento de todo carácter inventivo, lo cual guarda correspondencia con el binarismo de lo femenino-masculino y el desigual reparto del mundo simbólico-político basado en la asignación diferenciada de funciones y espacios según las naturalezas sexo-genéricas: privadoemocional-femenino versus público-racional-masculino. La designación de la esfera privada como nicho del destino femenino convierte la privación en un modo de existencia para las mujeres, una vía para menguar su lugar social.

Vivir una vida privada por completo significa por encima de todo estar privado de cosas esenciales a una verdadera vida humana; estar privado de la realidad que proviene de ser visto y oído por los demás, estar privado de una "objetiva" relación con los otros que proviene de hallarse relacionado y separado de ellos a través del intermediario de un mundo común de cosas, estar privado de realizar algo más permanente que la propia vida [...] [el ser] privado no aparece y, por tanto, es como si no existiera. (Arendt, 1998: 67)

Por esta razón, rebajar el texto de Suncín a simples impresiones o anécdotas de su vida en común con el autor francés no solo se opone a cualquier intento de resignificación pública y trascendente de su vida y figura, sino también muestra con claridad la desaprobación a la cual se exponen las voces femeninas autoriales que osan cruzar las lindes sexo-genéricas al incursionar en la palabra e irrumpir en la esfera pública, masculina por antonomasia. Esta transgresión es agravada en este caso por trastocar presuntamente el imago consagrado de Antoine de SaintExupéry, sobre todo al referir las desavenencias maritales, los problemas económicos, los altibajos de carácter y los problemas dentro de la pareja derivados de llevar una vida por encima de las posibilidades financieras, sobre todo en los períodos en los cuales Antoine no tenía trabajo o se encontraba en un desierto inventivo, sin escribir ni publicar. Circunstancias a las cuales se suman las incontables aventuras amorosas del escritor francés, sus ausencias de casa, salidas injustificadas y la descarada decisión de alquilar un piso para su amante en el mismo edificio en el cual convive con su esposa.

La autobiografía constituye una revelación pública de la interioridad. Pero la mujer definida culturalmente como pura domesticidad era una 
criatura encasillada en su interioridad. Declararse sujeto autobiográfico equivalía a invadir el territorio verbal en el que operaban los hombres. Hablar o escribir en público exponía a la mujer escritora a la terrible fuerza de la opinión pública, ese lector anónimo que podía destruir fácilmente la reputación de una mujer, su identidad genérica como construcción cultural de la feminidad. (Torras, 1998: 68)

Además, a la táctica empleada por Alain Vircondelet que Joanna Russ (2018) denomina rasero de contenido, se le suma otro giro cuando el prologuista emplea el criterio amoroso como programa de lectura. ${ }^{9}$ Esta estrategia posiciona en un solo movimiento tanto el texto como la voz narrativa: las memorias narran una historia de amor y el "yo" memorial, en su ejercicio de esposa abnegada, llega a convertirse en madre de aquel hombre a quien profesa un amor incondicional. Dicha postura le permite al crítico concebir Memorias de la rosa (2000) como una vía complementaria para acercarse al autor francés: "la relación entre Consuelo y Antoine de Saint-Exupéry es fundamental para conocer al escritor. Sin Consuelo, ¿sería realmente Saint-Exupéry? La aparición de estos documentos lo devuelve a su propia humanidad. Después de todo, ¿qué más da si el mito se resquebraja un poco? ¿Si el retrato ya no es exactamente el mismo que el que se dibujó para la eternidad?" (Vircondelet en De Saint-Exupéry, 2000: 17). Esta encorsetada propuesta de lectura muestra cómo opera la crítica para eclipsar una obra-autoría y cómo los intereses ideológicos (patriarcales-literarios) conducen al desvarío y a la contradicción con tal de no ceder espacios a quienes se considera que no los merecen. De modo arbitrario, el prefacio reconoce que la figura de Antoine de SaintExupéry es el resultado de una construcción mítica "demasiado perfecta" que oculta más de lo que revela (Vircondelet en De Saint-Exupéry, 2000: 20), pero asume "verdadero" el texto de la autora salvadoreña, al cual le confiere tácitamente el rango de documento referencial. Este enrevesado juego discursivo procura mover las piezas a conveniencia para hacerlas calzar dentro de un puzle que, finalmente, inscribe las memorias como una verdadera historia de amor que humaniza a Antoine de Saint-Exupéry.

Por tanto, la aparente contradicción de Alain Vircondelet no resulta nada fortuita. Ceñirse a la concepción tradicional del género memorialista — “escribió para contar su historia y explicar su verdad" (Vircondelet en De Saint-Exupéry, 2000: 20) - le permite ejercer un sutil y violento desplazamiento: Suncín narra "su

\footnotetext{
9 “Todo el libro es la historia de un hombre que parte y huye, que esquiva y atrapa. Que escapa y regresa, que se busca y no se encuentra. En el centro de la problemática: amar, pero sobre todo ser amado. Presencia de la madre tutelar, guardiana del hogar, la madre que preside una infancia encantada, la madre imagen de la fidelidad y de la permanencia" (Vircondelet en De Saint-Exupéry, 2000: 17).
}

96

Lectora, 27 (2021): 89-106. ISSN: 1136-5781 D.O.I.: 10.1344/Lectora2021.27.4 
verdad", pero ésta no trasciende, no roza la verdad con mayúscula - histórica, pública, masculina. La voz memorial no es sujeto-objeto de verdad. Por ello, la homologación Memorias de la rosa (2000) igual a verdad subjetiva se traduce en tachadura, borramiento, expropiación escritural-autorial, y su efecto inmediato es el despojo de su valor político y la asignación de una lectura frívola, anecdótica, trivial. Este giro retórico conceptual planteado por Alain Vircondelet coloca los reflectores sobre las problemáticas que acompañan la delimitación de las fronteras que definen y separan los géneros autobiográficos y su pacto tácito con las políticas sexo-genéricas. Así, la marca memorial propuesta por el paratexto se desplaza en la lectura del prologuista hacia la experiencia personal, movimiento que evidencia una identificación de doble dimensionalidad genérica: literaria y sexual, donde lo autobiográfico se vincula mayormente a lo personal, femenino, cotidiano e interior en contraposición a las memorias, asociadas a los hechos trascendentes, históricos, colectivos, atribuidos a los hombres de acción: guerreros, políticos, figuras públicas (Fallas, 2013).

Dicho esto, el mecanismo lecto-escritural empleado por Vircondelet produce un doble rebajamiento: la voz femenina no es sujeto de verdad y el texto carece de trascendencia pública. Por ende, salomónicamente las memorias son leídas como texto complementario para conocer más sobre la vida personal de Antoine de Saint-Exupéry. Precisamente esta descalificación inaugural, aferrada a patrones miméticos-referenciales y narrativas sexistas cercenadoras, convierte lo memorial en motivo de debate. Este propósito abre el siguiente apartado.

\section{Esquirlas de un “yo" memorial}

Doxológicamente la memoria es considerada el hábitat del recuerdo, se le figura el sitio de resguardo de la experiencia y del pasado, un baúl, álbum fotográfico o disco duro capaz de archivar lo vivido a través del tiempo y mantenerlo bajo custodia a la espera de cualquier visita, solicitud y evocación inducida o espontánea. La sensación de tranquilidad que esta imagen procura transmitir a los sujetos respecto al paradero de sus vidas y la contención del tiempo es en grado sumo ilusoria, no solo a causa de la imposibilidad de concreción (lo temporal y lo vivido resultan inaprehensibles), sino también porque se pasa por alto que la memoria es ante todo un ejercicio: un hacer memoria. ¿Qué supone esto?

Reconocer que la memoria comporta una práctica implica admitir que ésta no significa visitar recuerdos o recuperarlos, sino construirlos porque éstos no aguardan en un sitio tangible ni se hallan ordenados cronológica y alfabéticamente en la carpeta del pasado. Antes bien, la memoria trabaja, desde el presente, en su propio inventario con algo más que simples reminiscencias. Para profundizar en ello, conviene remontarse al pensamiento platónico (Teeteto y El sofista), donde la memoria $(e i k \bar{n} n)$ constituye la representación en el presente de una cosa ausente, cuya 
impresión primera marca una huella (corporal, cortical) en el sujeto. Esta noción se encuentra vinculada con la propuesta aristotélica, en la cual la memoria concebida como afección (pathos) constituye la representación de una cosa percibida o aprendida en el pasado.

Siguiendo este razonamiento, hacer memoria consiste entonces en crear en el presente una representación tanto de lo percibido como de lo ausente, a partir del registro-impresión de la experiencia pasada. Operación en la cual la interpretación se convierte en puente, pues la marca/impresión de lo vivido solo llega a ser representable como imagen tras un proceso de lectura - valga decir- no siempre idéntico. Esto significa que, aunque se trate de un mismo evento, sitio o persona, su existencia como recuerdo no permanece incorruptible, está condicionada por la naturaleza temporal de su hacedora/hacedor. El transcurrir del tiempo y la acumulación de diversas experiencias no solo transforman la vida de los sujetos, sino también sus nexos con lo vivido y los modos de reconfigurar los recuerdos, lo que conduce a aceptar que no siempre se recuerda del mismo modo. Por ello, al margen de toda preconcepción, la memoria no permanece anclada al pasado, es siempre un hacer en/desde el presente, posibilidad inventiva. Lo vivido y lo pasado solo pueden "vivir" en el discurso como imagen, esto es: la representación de otra cosa.

Partiendo de dichas consideraciones, este estudio se distancia de la lectura de Vircondelet para prestar atención a las autofiguraciones narrativas que progresivamente van tejiendo y personificando (en el sentido retórico del término) el "yo" de Memorias de la rosa (2000). En este ejercicio adquieren relevancia los procesos de filtraje, retoque y creación de puentes imaginario-discursivos (empleo de mecanismos discursivos para crear secuencialidad y estrategias ficcionales para conferir unidad narrativa al relato), ya sea en apego o reacción a las normas, valores ideológicos de una época-contexto particulares (censura, prejuicios) e intereses que motivan la tarea de dar cuenta de sí (Butler, 2009a, 2009b).

Memorias de la rosa (2000) inaugura su relato en medio del mar, la voz narrativa se halla a bordo del Massilia y viaja a Buenos Aires por invitación del Gobierno argentino, en representación de su difunto marido, el diplomático y autor guatemalteco, Enrique Gómez Carrillo (1873-1927). Al llegar a la ciudad, tiene lugar el encuentro con Antoine de Saint-Exupéry, hecho narrativo que se convierte en retablo de la secuencia memorial en devenir y del “yo" derivado de ésta. De acuerdo con el texto, la figura de la voz narrativa llama la atención del aviador y escritor francés, quien le solicita no marcharse y, en un intento por retenerla, la empuja a un sillón. Benjamín Crémieux, amigo en común, atestigua este hecho y los presenta. La situación incomoda a la voz memorial, quien de repente queda sumergida en un sofá alto y profundo, intentando hacer llegar las puntas de sus pies a la alfombra, pasaje que delinea un "yo" definido por las marcas sexo-genéricas de lo

98

Lectora, 27 (2021): 89-106. ISSN: 1136-5781 D.O.I.: 10.1344/Lectora2021.27.4 
femenino, asociadas a la asimetría y el replegamiento, posiciones desde las cuales habla y se figura la voz narrativa a lo largo de las memorias.

Yo me sentía molesta, ridícula, una especie de muñeca que emitía ruidos cuando intentaba hablar. Me parecía que las palabras que pronunciaba carecían de sentido. Su mano pesaba en el brazo, y a mi pesar me sentía su víctima, inmovilizada en aquel sillón de terciopelo, sin posibilidad de escape. [...] Empecé a sentirme indignada con la naturaleza femenina. Hice un último esfuerzo, el de una luciérnaga que emite su última chispa de luz, de ingenio, de fuerza.

Intenté extirparme del sillón y dije despacio:

-Me voy.

Él me cortó el paso con sus grandes brazos. (De Saint-Exupéry, 2000: 33)

"Muñeca", "víctima", "luciérnaga" no constituyen simples y alegóricas identificaciones de la voz textual, sino un modo de lecto-escribirse desde las normas y los códigos propios del modelamiento binario: lo femenino en oposición a lo masculino, asumido este último desde una dimensión universal. Así pues, aquellas identificaciones integran el campo semántico de lo etéreo, lo subyugado, lo rebajado; esto es, lo mudo, lo estático, sin alas. Por tanto, este episodio sobrepasa todo candor atribuible al recuerdo del primer encuentro con el ser amado y, en su lugar, se convierte en augurio y referente del autorretrato del yo-textual. En correspondencia con el ideario social que la precede como mujer y el sello de ese primer intercambio, al cual le sigue una petición de matrimonio apresurada, el destino del "yo" narrativo queda trazado de forma definitiva.

En apego al constructo social del deber ser, la voz narrativa de Memorias de la rosa (2000) se autofigura como la mujer-esposa de un reconocido escritor, donde cobra valor su abnegación, sacrificio y renuncia de sí (auto-borramiento) a causa o en nombre de quien ama. En consonancia, el "yo" se representa también como esposa-musa, figura que procura brindarle al autor francés las mejores condiciones durante sus procesos creativos: "Era preciso ayudarle en sus esfuerzos, en sus luchas, en el penoso parto de sí mismo, de sus libros, en medio de todas las preocupaciones cotidianas que lo asediaban y en medio de todos los que no adivinaban aún que algo en su corazón había entrado en diálogo con Dios" (De Saint-Exupéry, 2000: 129). La voz narrativa acompaña al escritor mientras trabaja, lee sus textos y brinda recomendaciones, conoce los detalles de las historias de sus obras y alega ser quien lo inspira. ${ }^{10}$ Mas, al margen de la idealización de la musa, la voz memorial

${ }^{10}$ La voz narrativa sostiene que la obra Vuelo nocturno (1930) se gesta a partir de una carta de
amor que el autor le dedica a ella: "Su libro Vuelo nocturno nació de esa carta de amor" (De Saint-
Exupéry, 2000: 40). Y su más célebre obra, El principito (1943) también: "Había dejado unas letras 
muestra su cara esclavizante, su ejercicio parece ser una forma romantizada y mitificada de servir, esto es, ser secretaria, oyente, amante, párvula, todo en un solo cuerpo-sujeto. En esta línea, Teresa Fallas sostiene que la obra de Suncín:

[...] recrea las experiencias de aquellas que debieron renunciar a su propia creación en beneficio de su pareja, al convertirse en asistentes y animadoras de los maridos y limitarse a rodearlos de una atmósfera atrayente para su desarrollo literario. Antes de casarse, época en la cual Antoine de Saint-Exupéry aún era un desconocido, la escritora salvadoreña se inhibió, artísticamente, para apoyar la producción literaria del escritor francés, aunque era escritora, escultora y pintora. (Fallas, 2013: 62)

Por ello, el precio que debía pagar Suncín por ejercer de musa resultaba ser bastante alto: debía empequeñecerse, replegarse para engrandecer al otro; eclipsarse para hacer brillar a su marido. Así lo evidencia el siguiente fragmento:

Pero Tonio, además, quería leer, Tonio quería escribir. Así pues, yo tenía que hacerme pequeña, tenía que vivir en sus bolsillos. Hacía dibujos que no se parecían a nada. Si eso lo ponía nervioso, me dedicaba a bordar. Y los almohadones bordados se amontonaban encima del sofá. Le gustaba que estuviera en la misma habitación que él cuando escribía; y cuando se quedaba sin ideas, me pedía que lo escuchara, y me leía una, dos, tres veces sus páginas y esperaba mis respuestas. (De Saint-Exupéry, 2000: 102103)

No obstante, no todo es brindar inspiración para la esposa que sirve de musa. La memorialista refiere las desavenencias maritales, infidelidades, problemas económicos, conflictos existenciales, deslealtades, separaciones, circunstancias que tejen en la narración la figura de una esposa mártir, capaz de soportar desprecios, humillaciones y ejercer determinadas funciones ${ }^{11}$ como prueba de su amor $y$

y un bonito dibujo que era su retrato: un payaso con una flor en la mano, muy confuso, un payaso torpe que no sabía qué hacer con su flor... Más tarde, supe que la flor era yo, una flor muy orgullosa, como dice en El principito" (De Saint-Exupéry, 2000: 186).

${ }^{11}$ La voz narrativa no comparte el estilo de vida bohemio del círculo de amigos de su marido ni asimila la exposición pública de su vida matrimonial. Admite que no encaja en ese mundo, pero tiene la obligación de permanecer en él: "[...] y me daba cuenta de que no estaba hecha para ser la esposa de un escritor de moda; compartir nuestras risas y nuestra intimidad con otra gente seguía pareciéndome una catástrofe" (De Saint-Exupéry, 2000: 143); "Sí, yo no estaba a la altura [...]. Para toda la gente que te adulaba, yo fui siempre la pequeña Consuelo, la española, la mujer que hace escenas" (De Saint-Exupéry, 2000: 220).

100

Lectora, 27 (2021): 89-106. ISSN: 1136-5781 D.O.I.: 10.1344/Lectora2021.27.4 
compromiso conyugal: “¡Dios mío, ser la mujer de un piloto es un oficio; pero serlo de un escritor es un sacerdocio!” (De Saint-Exupéry, 2000: 221). Surge, entonces, la autoimagen de una Penélope, quien no posee vida si no es aguardar. La voz textual se encuentra continuamente a la espera de su marido, sea por su trabajo como aviador, a causa de la guerra o porque él se encuentra con alguna de sus amantes: “¿Cuál era, de verdad, mi papel? ¿Cuál era mi deber inmediato? Esperar, esperar, esperar siempre" (De Saint-Exupéry, 2000: 132).

Si bien las figuraciones musa, mártir y Penélope aportan rasgos distintivos al "yo" textual, éstas coinciden en remarcar el replegamiento y reducción de su figura, tal como lo presenta la secuencia del encuentro y la impostura de la esposaniña, perfil caracterizado por la dependencia, la fragilidad y la falta de conocimiento: "Con él me sentía desarmada y perdía todo mi sentido práctico. Como una niña pequeña” (De Saint-Exupéry, 2000: 86). En la posición esposa-niña, el "yo" narrativo queda despojado de autonomía, se abandona a otro, entrega su poder, lo cede a su marido, ${ }^{12}$ quien simbólicamente ocupa la posición de padre. Imagen que crea como contrapeso a la esposa-madre figura que, en su entrega y amor mal entendido, se desplaza hacia otro ideario femenino. ${ }^{13}$

Estas construcciones figurativas derivadas de la marca sexo-genérica se traslapan con otra narrativa lecto-escritural adherida al cuerpo del "yo"-memorialista: el origen étnico y la extranjería, la cual se inscribe desde dos sitios: adentro ("yo"), afuera (el otro). La mirada del "yo" delineada por el relato homologa la nación de procedencia, El Salvador, como la raíz, la sangre: la cuna. Esta autoconcepción, en numerosas ocasiones, se empaña de nostalgia y arraigo: "Cuando me dormía en París, soñaba con volver a ver mi sol, esa luz, mis volcanes retumbantes como cañones, el eterno verano; durante mucho tiempo había soñado con reencontrarme en esa atmosfera que era mi cuna, mi sangre" (De Saint-Exupéry, 2000: 165). El Salvador se erige como el lugar de resguardo por excelencia donde se halla la familia, los primeros recuerdos, la cultura indígena y mestiza que recorre su linaje. La voz de Memorias de la rosa (2000) se identifica y reconoce, de manera dispersafragmentada, en diversos elementos imaginarios y simbólicos que alimentan la

\footnotetext{
${ }^{12}$ Sirvan como ejemplo las palabras que, dentro del mundo narrado de Memorias de la rosa (2000), Antoine de Saint-Exupéry dirige a Consuelo: "Me sorprende tener a mi lado a una niña pequeña como tú” (De Saint-Exupéry, 2000: 91); “-¿Tú, trabajar? ¡Pero si eres demasiado frágil!” (De Saint-Exupéry: 2000: 185).

${ }^{13}$ La voz narrativa legitima ese rol a partir del reconocimiento de Antoine de Saint-Exupéry: "-Pero ahora sé muchas cosas. Ya no tengo miedo de alejarme de ti. Me quieres como a un padre, me cuidas mejor de lo que sabría hacer una esposa de tu edad. Mamá de un hombre calvo" (De Saint-Exupéry, 2000: 115).
} 
concepción ${ }^{14}$ exótica manejada desde afuera sobre Latinoamérica: volcanes, terremotos, vegetación exuberante, fauna y flora silvestre, frutos tropicales, mundo indígena. Respecto a este último, destaca la alusión a sus rituales. En un recuerdo sobre las visitas a su pueblo, los indígenas de Izalco realizan un desfile en honor a la llegada de la voz memorialista y le entregan ofrendas para darle la bienvenida (De Saint-Exupéry: 2000: 176). A esta imagen se suma la referencia a los zahoríes y los rituales asociados a la lluvia, al eco de un mundo y a una cosmovisión prehispánica arrebatada:

En esos días de angustia en los trópicos, los terratenientes se reunían al claro de luna, encendían grandes hogueras en los patios, preparaban café y entonaban oraciones para que viniera la lluvia. A veces se producía el milagro y el agua, tan deseada y esperada, volvía a poner en pie a miles de ovejas. Nadie podía decir cuáles de los hombres que rezaban iban a ser ricos o pobres al día siguiente. (De Saint-Exupéry, 2000: 133)

Este abanico de identificaciones e imágenes entra en tensión con la mirada de los otros y crea otra posición enunciativa donde el "yo" se articula desde la diferencia: "Yo tenía otro origen, otra tierra, otra tribu, hablaba una lengua distinta, comía cosas distintas, vivía de manera distinta” (De Saint-Exupéry, 2000: 73). La extranjeridad representa discordancia: para la familia Saint-Exupéry, ${ }^{15}$ los amigos y allegados, Consuelo desentona, se halla fuera de lugar. En un intento por legitimarse desde la clase social y abolengo, la voz memorial echa mano de su árbol genealógico y el de su difunto marido:

Los Carillo también poseían títulos de nobleza, había un marqués, y los Sandoval formaban parte de la mejor sociedad [...]. En mi familia había curas y hasta cardenales [...]. Yo tenía una buena dosis de sangre india

\footnotetext{
${ }^{14}$ Las biógrafas Marie-Hélène Carbonel y Martine Fransioli Martínez (2010) denominan a Consuelo de Saint-Exupéry la "Shéhérazade des tropiques", asociando el imaginario atribuido a las naciones latinoamericanas (belleza, exotismo, furia de la naturaleza, inestabilidad y pobreza) con los recursos inventivos-discursivos para contar esas realidades, eco de la concepción del realismo mágico, una lectura que subyace la asignación del epíteto y otras valoraciones: "[...] que serait devenu Le Petit Prince si Consuelo n'était pas née au pays des volcans et des roses qui poussent à leurs pieds?" (Carbonel y Martínez, 2010: 61); “Le génie du conteur n’est-il pas de transformer la force des choses en histoires merveilleuses? Les Latino-Américains détiennent, de toute évidence et depuis des siècles, le secret de ces métamorphoses" (63).

${ }^{15}$ Con excepción de la madre de Antoine de Saint-Exupéry, quien "[...] con su inteligencia poco común y su fe cristiana, quería únicamente la felicidad de su pequeño. A sus ojos, yo no había cometido ningún crimen al no nacer en Francia [...]. Me ofreció toda su simpatía" (De SaintExupéry, 2000: 74).
}

102

Lectora, 27 (2021): 89-106. ISSN: 1136-5781 D.O.I.: 10.1344/Lectora2021.27.4 
maya (algo que estaba de moda en París) por la parte Suncín, y conocía leyendas de volcanes que podrían divertirlos [...]. Pero algo más profundo los frenaba, algo relativo a las mezclas de sangre. (De Saint-Exupéry, 2000: 73)

Se infiere de dicho fragmento que los privilegios de su clase, su fortuna y clan familiar burgués no alcanzan a compensar el peso de su sangre, el estigma de su origen. La marca imperialista sella su cuerpo-“yo" memorial como non grato, invisible: "Yo no era francesa, no querían verme ni conocerme, cerraban los ojos ante mí” (De Saint-Exupéry, 2000: 74). La voz del “yo” replegada en su primer territorio (cuerpo), debido a las marcas sexo-genéricas, es ubicada en la periferia a causa de su procedencia.

\section{Espacio memorial como espacio de reconocimiento}

Al perfil memorialista antes esbozado se adhiere el "yo" autorial. Paralelamente a la narración cronológica de la experiencia, la voz narrativa crea de modo progresivo un lugar de enunciación y un rostro asociado al ejercicio escritural ensamblado a medida a la autofiguración de esposa extranjera. Dos mecanismos discursivos lo evidencian con claridad: el reconocimiento figurado de Saint-Exupéry y el reclamo de la voz memorial en pro de ocupar un sitio dentro de su mundo literario, leyenda y acto creativo.

De tal manera, delinear el "yo" narrativo desde los perfiles esposa - musa, mártir, Penélope, niña, madre y mujer de tierras lejanas - coloca a la voz del "yo" en la performance-encarnación de varios corsés de lo femenino circunscritos al paradigma falocéntrico-patriarcal, lo cual luego contribuye a formular retóricamente su alegato y posterior demanda: la retribución de un reconocimiento en pago de ello. En este sentido, la voz narrativa no posiciona un "yo" como arquetipo de lo femenino tan solo para crear el marco de una vida en común, hacer un recuento de experiencias o mostrar una versión más humana (menos mítica) de Antoine de Saint-Exupéry. Memorias de la rosa (2000) figura un "yo" para otorgarle, a través de la escritura, un valor-lugar negado extraliterariamente por su marido, su círculo de amigos, la sociedad y la crítica. Pretensión o búsqueda narrativa que le confiere al texto un tono político difícil de eludir, aunque la crítica lo soslaye y opte por desviar la mirada hacia Antoine de Saint-Exupéry.

En una de las secciones finales de las memorias, titulada por el editor "Nunca he dejado de quererte", la voz textual narra un diálogo con su marido, recurso empleado para resignificar su lugar desde la voz del otro. En dicho parlamento Antoine de Saint-Exupéry reconoce la trascendencia de la figura y la labor de la voz memorial tanto en su obra como en su vida personal. Admite que el "yo" narrativo es el germen de su creación literaria, la musa cocreadora de Vuelo nocturno (1931) 
y El principito (1943), así como la rosa ${ }^{16}$ del personaje de esta obra (imagen rescatada por el título de las memorias): "Es muy posible, por lo demás, que yo no tenga nada que darte; pero tal vez tú sí puedas darme algo, cultivarme, plantar en mí una semilla, enriquecerme, compensar mis pérdidas para que yo pueda crear, continuar mi gran poema, el libro en el que querría poner todo mi corazón. Eres la primera que creyó en mí, para ti escribí Vuelo nocturno" (De Saint-Exupéry, 2000: 241).

En este mismo diálogo Antoine de Saint-Exupéry reconoce la devoción y sacrificio de su esposa, las dificultades que ha enfrentado a causa de él, los injustos tratos de sus amigos al señalarla como causa de sus conflictos personales y maritales. Esta declaración cierra con una concesión significativa que le otorga el título de escritora, tras regalarle una máquina de escribir y un dictáfono: “- $[. .$.$] Porque$ eres una gran poeta, Consuelo. Si quisieras, llegarías a ser mejor escritora que tu marido..." (De Saint-Exupéry, 2000: 243). La fuerza que encierra este reconocimiento permite comprender tanto la construcción del "yo" articulada por las memorias como su búsqueda: el reclamo de un lugar imaginario-discursivo. Finalmente, dentro de un mundo textual que inscribe el "yo" desde la tachadura, éste solo puede gestarse a través del valor otorgado por el otro. Por ello, textualizado el matrimonio Saint-Exupéry y su historia, Antoine reescribe metatextualmente a la voz memorial: el otro creado por el relato del "yo" da a luz a otro "yo". El espacio memorial se trueca al unísono en espacio de autoconcepción, de reconocimiento, de deuda saldada. ${ }^{17}$

Se alude a una "deuda saldada", pues la voz narrativa en una de las entradas iniciales de las memorias, al referir la publicación de Vuelo nocturno y la admiración de su círculo cercano (Gide, ${ }^{18}$ Crémieux, Valéry), expresa que su grado de vinculación en el proceso creativo y el seguimiento de su trabajo día tras día la conducen a creer que entrega un regalo a los otros, que ofrece a los lectores un trozo de sus vidas (la suya y la de su marido). Sin atreverse a pronunciarlo, el "yo" textual se perfila desde la autoría compartida. Para contrarrestar la osadía de dicha afirmación se desdice, cataloga su actitud de torpe e ingenua, y con un aire de reproche concluye: "Yo era tonta. Creía que yo también tenía derecho a la

\footnotetext{
16 “Arréglame la corbata. Dame tu pañuelo para escribir en él la segunda parte de El principito. Al final de la historia, el principito dará este pañuelo a la princesa. Ya nunca más serás una rosa con espinas, sino la princesa de ensueño que siempre espera al principito. Y te dedicaré el libro. No puedo consolarme por no habértelo dedicado" (De Saint-Exupéry, 2000: 260).

${ }^{17}$ Eso podría leerse entre líneas en la promesa figurada de Antoine de Saint-Exupéry: "Si me amas, lucharé por ofrecerte un nombre famoso, tan importante como el de tu marido, Gómez Carrillo" (De Saint-Exupéry, 2000: 53).

${ }^{18}$ Gide escribe el prefacio de Vuelo nocturno (1930).
}

104

Lectora, 27 (2021): 89-106. ISSN: 1136-5781 D.O.I.: 10.1344/Lectora2021.27.4 
admiración por su obra. Creía que era de los dos... ¡Qué error! Para un artista, no hay nada más personal que su creación: aunque le entregues tu juventud, tu dinero, tu amor, tu valor, nada de ella te pertenece" (De Saint-Exupéry, 2000: 85). Colocar esta demanda frente al reconocimiento atribuido por Antoine de Saint-Exupéry permite leerla como impostura, recurso que a la luz de este análisis subraya la búsqueda de la escritura memorialista: revertir la tachadura.

En suma, contravenir la lectura sesgada y excluyente propuesta por el prefacio de Alain Vircondelet evidencia de qué modo opera el aparato crítico cuando una obra y una figura autorial no se ajustan a determinados valores ideológicos ni a los parámetros genéricos sexo-literarios. La posición periférica de la salvadoreña Consuelo Suncín Sandoval, debido en gran medida a su origen, se proyecta a su trabajo artístico y escritural, donde converge con los atavismos de lo femenino, lo cual simplifica la operación de la crítica. Memorias de la rosa (2000) es despojada de la carga política inherente a todo discurso memorialista y es reemplazada por el carácter ligero y frívolo de los recuerdos de pareja, la historia de amor y su aporte al retrato legendario de su marido. Al devolverle su lugar al "yo" memorial cobra forma una figura femenina-escritural en busca de reconocimiento, la voz de Consuelo de Saint-Exupéry emerge de la penumbra eclipsante donde fue enviada a gravitar para solicitar ser parte de esa historia mítica que ella misma sostuvo y construyó, tal como lo constatan sus memorias.

\section{REFERENCIAS BIBLIOGRÁFICAS}

Arendt, Hannah (1998), La condición humana, Barcelona, Paidós.

Butler, Judith (2009a), Dar cuenta de sí mismo. Violencia ética y responsabilidad, Buenos Aires, Amorrortu Editores.

-(2009b), Lenguaje, poder e identidad, Madrid, Síntesis.

Carbonel, Marie-Hélène y Martine Fransioli Martínez (2010), Consuelo de SaintExupéry: Une mariée vêtue de noir, París, Éditions du Rocher.

Catelli, Nora (1991), El espacio autobiográfico, Barcelona, Lumen.

De Man, Paul (1991), “La autobiografía como desfiguración”, Anthropos, 29: 113 118.

Derrida, Jacques (1998), Memorias para Paul de Man, Barcelona, Gedisa.

De Saint-Exupéry, Consuelo (2000), Memorias de la rosa, Barcelona, Ediciones B. Fallas, Teresa (2013), Escrituras del yo femenino en Centroamérica 1940-2002, San José, Editorial de la Universidad de Costa Rica.

Gay, J. Víctor (2001), “Consuelo de Saint-Exupéry, la rosa del Petit Príncep, a Cadaqués”, Lletres, 207: 38-41, 27/09/20. <www.revistadegirona.cat> 
Genette, Gérard (1989), Palimpsestos. La literatura en segundo grado, Barcelona, Taurus.

Loureiro, Ángel (1991), "Problemas teóricos de la autobiografía”, Anthropos, 29: 2-9.

Ricœur, Paul (1992), La función narrativa y el tiempo, Argentina, Editorial Almagesto.

-(1996), Sí mismo como otro, Madrid, Siglo XXI Editores.

-(2003), Teoría de la interpretación. Discurso y excedente de sentido, México, Editorial Siglo XXI.

-(2010), La memoria, la historia, el olvido, Madrid, Editorial Trotta.

Russ, Joanna (2018), Cómo acabar con la escritura de las mujeres, Sevilla \& Madrid, Editorial Dos Bigotes \& Editorial Barret.

Torras, Meri (1998), "La epístola privada como género: estrategias de construcción”, Tesis Doctorals en Xarxa, Universidad Autónoma de Barcelona, 04/06/20. <https://hdl.handle.net/10803/32188> 